\title{
TRENDS IN DEVELOPMENT OF SERBIAN AGRICULTURE AFTER THE ECONOMIC CRISIS IN 2008. ${ }^{1}$
}

\author{
Jugoslav Aničićz, Vesna Paraušić 3
}

\begin{abstract}
In this paper, the authors analyse the trend of agricultural production, at the agricultural holdings and enterprises active within the mentioned sector, in the period after the economic crisis in 2008., based on the submitted financial reports. The fact is that Serbia has favourable natural resources, but the achieved results are significantly below the average of EU member states. This indicates low labour productivity, as well as low competitiveness of legal entities involved in the agricultural sector. The analysis points out to the basic factors that influenced this state of the sector, but also to the possibilities of its dynamic and sustainable development. There is believe that participants in the production and trade of agricultural products can make a significantly greater contribution to overall economic growth, employment, exports and the creation of new value, but they need an adequate business environment and support of agricultural policy.
\end{abstract}

Key words: sector of agriculture, sustainable development, family farm, agricultural policy.

JEL" Q10, Q18

\section{Introduction}

The transition results of the agricultural sector show that Serbia has not yet created a favourable environment for the development of business of participants in the production-distribution chain of this sector. This is particularly true for family farms and the sector of the micro and small enterprises, which with their share in gross value added, employment and exports, represent a significant segment of the entire economy. Regardless of numerous advantages in terms of favourable climatic conditions, quality of the land, and other comparative advantages, the average

1 Paper is a part of research funded by the Ministry of Education, Science and Technological Development of the Republic of Serbia according to signed agreement no. 451-03-68/202014/200009.

2 Jugoslav Aničić, Ph.D., Full Professor, University Union "Nikola Tesla", Faculty for economy and finance, Belgrade, Serbia, Phone: , E-mail: ajugoslav@yahoo.com

3 Vesna Paraušić, Ph.D., Senior Research Associate, Institute of Agricultural Economics, Volgina Street no. 15, 11060 Belgrade, Serbia, Phone: +381 116972 858, E-mail: vesna_pa@iep.bg.ac.rs

4 Article info: Review Article, Received: $4^{\text {th }}$ December 2020, Accepted: $13^{\text {th }}$ December 2020. 
income of farms in Serbia is significantly lower than the EU-27 average, which expresses lower productivity in agriculture, as well as opportunities for long-term and sustainable development of the whole mentioned sector.

In order to achieve this, it is necessary to change the economic and agricultural policy active in the sector, starting with the structural reform of the producers and rural areas. This sector was unprepared for the transitional changes and the impact of the globalization, which resulted in its great decline and long recovery in terms of returning to the developed world markets. Consequently, in the structure of production and exports of the agri-sector is dominating the raw products, with little derived added value. There is also a weak horizontal and vertical linkage, both within the sector and with other sectors of the economy. Therefore, one of the main tasks of agricultural policy is to utilize unquestionable available potentials of the sector, as well as to increase the productivity and competitiveness of the sector, which would greatly increase its contribution to overall development.

In paper are presented the results of total agricultural production in the period after the great economic and financial crisis in 2008., as well as its structure and occurred trends. Through the data of representative public institutions, the positions and possibilities of the sectors of family agricultural holdings and agricultural enterprises were separately analysed on the basis of the submitted financial reports. The objective of this paper is to highlight to policy makers the trends active in the agricultural sector, as the previously identified weaknesses and threats to further development, along with the opportunities of the observed sector for accelerated development.

\section{Methodology and Used Data}

Research involves the use of several scientific methods such are desk research and historical method, or deduction and comparative method. Paper is strongly consulted with national legislation and strategic documents turned to the sector of agriculture, as well as data gained from certain public institutions as are Ministry of Agriculture, Forestry and Water Management of the Republic of Serbia and the Statistical Office of the Republic of Serbia. Besides, verification of derived conclusion is in line to national and international scientific and professional literature sources directed to agriculture.

\section{Trend of Agricultural Production in the Post-crisis Period}

Despite the fact that the share of agriculture is increasing with decrease in the economic development of certain country, some developed countries are achieving significant share of agriculture in their foreign trade balance (e.g. the Netherlands, 
Canada, Australia, Denmark, or France). In the contemporary, globalized world, it is necessary to increase food production, as well as to timely distribute agrifood products to all parts of the Earth (Stefanović, Broćić, 2012). There is a need to recognize the multiple role of agriculture and its impact on other sectors and overall economic development (Byerlee et al., 2009). Above the all, usually the slower development of agriculture towards the other sectors of economy is the consequence of inconsistence in defining and implementation of its developmental concept (Devetaković et al., 2009).

The great importance of the agricultural sector is indisputable, but still has not been created sufficiently stimulating socio-economic environment for the viable development of villages and agriculture, especially in certain regions of the Republic of Serbia (Ristić, 2013). Opportunities for the development of mentioned sector are not even close to be fully used, so there is much more space for the boosting of its contribution to the overall sustainable development of the national economy. Tradition, fertile land, favourable climate, available natural resources, unpolluted environment, etc. represent the great comparative advantages of Serbian agriculture, but in the opposite direction are acting certain limiting factors such as obsoleted mechanization, atomised estates, insufficient utilisation of agri-technique, generally extensive production, unfavourable age and education structure, price disparity, unsure distribution channels and uncertainty in realization of agri-food products, low level of presence of certification or insurance in production, insufficient cooperation, etc. (Simonović et al., 2012; Mihailović, Vuković, 2017).

According to Pejanović et al. (2006), the transition in agriculture represents the skip from the previous model of agriculture to a new market oriented concept of business that is in line to model of agriculture practiced in developed EU countries. This process has been taken place through privatization and restructuring, and later through the creation of a favourable macroeconomic environment. But, mentioned process was largely slowed down by the emergence of the great financial crisis in 2008. Meanwhile, significant step forward in monitoring of the state of agricultural sector was the census of agriculture, which was carried out in 2012 after five decades.

Strategic goals and directions of agricultural development in Serbia are based on the Strategy of Agricultural and Rural Development of the Republic of Serbia for the period 2014-2024. (MAFWM, 2014).

Besides, as mid-term development documents covering this sector exist the National Program for Agriculture for the period 2018-2020. and National Rural Development Program for the period 2018-2020. These programs are operationalizing the strategic plan and envisage the measures and activities for adjustment of agricultural policy 
with the Common Agricultural Policy of the EU during the pre-accession period (MAFWM, 2017; MAFWM, 2018).

Two basic legal acts that regulate the sector of agriculture are the Law on Agriculture and Rural Development and the Law on Incentives in Agriculture and Rural Development. These laws establish the mechanisms for the adoption and implementation of agricultural policies, as well as they define beneficiaries and ways of incentives use, or amounts and types of incentives, etc. (MAFWM, 2015; MAFWM, 2016). Based on the Law on the Budget of the Republic of Serbia for 2019., some financial assets have been allocated for the implementation following incentives in agriculture: direct payments, rural development measures, credit support in agriculture, certain special incentives and IPARD program (GRS, 2018).

Due to the Serbian participation in European integration processes, one of the tasks is to harmonize with the EU economic model. Therefore, the Strategy of Agriculture and Rural Development of the Republic of Serbia for the period 2014-2024., among all has been establishing three most important segments of reforms: 1) reform of agri-policy, 2) establishment and full implementation of the legislative framework, and 3) Institutional reforms (MAFWM, 2014). Besides, in line to global trends of strengthening the overall sustainability of agriculture, intentions of current public policy and strategic priorities defined in mentioned document are also focused to agriculture based on science, research, technological development and innovation (Subić et al., 2017; Parausić, Domazet, 2018).

In Serbia, there is a weak connection of primary agriculture with the processing industry, trade, tourism, education, and other sectors. In rural areas, competitive agriculture can be a locomotive of local economic development and employment, and thus the survival of the population in these areas. To achieve this, participants in agricultural production and trade have to fully accept and understand market's rules and mechanisms, as well as to adopt entrepreneurial behaviour within the business they run (Jeločnik, Subić, 2020).

So, development and growth of the sector's competitiveness will mostly depend on entrepreneurial initiative and innovation. Transfer and application of the new knowledge and technologies, increase in productivity and penetration into the new markets are potentially the factors that have to be given more attention over the public incentives. On the other hand, the restrictive agricultural budget in recent years has been significantly lower than the requirements derived from the innovation and sustainable development (in average it has annual share in overall national budget of around 4\%), (Kuzman et al., 2017). 
Table 1. Agricultural output (goods and services) in producers' prices of current year (period 2010-2019., in million RSD)

\begin{tabular}{|l|c|c|c|c|c|c|c|c|c|c|}
\hline \multicolumn{1}{|c|}{ Description } & $\mathbf{2 0 1 0 .}$ & $\mathbf{2 0 1 1 .}$ & $\mathbf{2 0 1 2 .}$ & $\mathbf{2 0 1 3 .}$ & $\mathbf{2 0 1 4 .}$ & $\mathbf{2 0 1 5 .}$ & $\mathbf{2 0 1 6 .}$ & $\mathbf{2 0 1 7 .}$ & $\mathbf{2 0 1 8 .}$ & $\mathbf{2 0 1 9 .}$ \\
\hline Total (1+2) & 466,810 & 519,959 & 502,684 & 565,521 & 584,299 & 534,779 & 589,817 & 543,746 & 589,704 & 605,291, \\
\hline 1. Goods & 455,752 & 509,125 & 491,597 & 552,078 & 569,276 & 520,965 & 574,817 & 529,890 & 574,703 & 589,978 \\
\hline $\begin{array}{l}\text { Crop } \\
\text { production }\end{array}$ & 328,980 & 359,103 & 324,451 & 378,832 & 390,747 & 351,927 & 419,400 & 357,056 & 398,513 & 414,528 \\
\hline $\begin{array}{l}\text { Animal } \\
\text { production }\end{array}$ & 126,771 & 150,022 & 167,146 & 173,245 & 178,528 & 169,038 & 155,417 & 172,834 & 176,190 & 175,449 \\
\hline 2. Services & 11,058 & 10,834 & 11,087 & 13,442 & 15,023 & 13,813 & 14,999 & 13,856 & 15,000 & 15,310 \\
\hline
\end{tabular}

Source: SORS, 2020.

According to the data in Table 1., it could be noted significant increase in agricultural output (production of goods and services) in 2019. compared to the initial year of observed period (for around 30\%). In the total value of produced agri-food goods and services crop production generally participates with over $60 \%$, while animal production share is slightly above one third.

At the same time, the growth in crop production was $26 \%$, while the growth in animal production was over 38\%. Expressed variations (decrease in output value) in crop production was obvious in 2012., 2015. and 2017., while the livestock production was quit a stable with no such a sharp decrease in produced output (Table 2.).

Table 2. Indices of gross agricultural production in Serbia (period 2010-2019., previous year $=100$ )

\begin{tabular}{|c|c|c|c|c|c|c|c|c|c|c|}
\hline Description & 2010. & 2011. & 2012. & 2013. & 2014. & 2015. & 2016. & 2017. & 2018. & 2019. \\
\hline $\begin{array}{l}\text { Agricultural production } \\
\text { - total }\end{array}$ & 100.5 & 99.6 & 78.5 & 124.4 & 104.6 & 92.8 & 111.6 & 84.5 & 116.1 & 101.5 \\
\hline Crop production & 100.7 & 99.1 & 69.7 & 139.5 & 106.3 & 87.3 & 119.5 & 76.5 & 125.5 & 101.9 \\
\hline Livestock production & 100.2 & 100.5 & 98.2 & 102.1 & 101.4 & 103.5 & 98.3 & 101.5 & 101.3 & 100.9 \\
\hline
\end{tabular}

Source: SORS, 2020; MAFWM, 2020.

In 2019., Serbia's largest foreign trade partner in exchange of agri-food products was the EU, with a share in total exchange of around 55\%. In exports, EU was participated with about $49 \%$, while in total imports it had a share of $65.3 \%$. Around $28.5 \%$ of the total exports were directed to CEFTA countries, while in same time from these destinations was imported only $9.5 \%$ agri-food products and services. The structure of foreign exchange in agri-food products and services is very unfavourable, as even $69 \%$ of the total exchange involves just raw agricultural products (in exports $72 \%$, while in imports 62\%), (MAFWM, 2020).

Agriculture is among the few sectors of national economy recording a foreign exchange surplus for years. Within the observed period, as main export agri-food commodities are usually marked mercantile corn and other cereals, fresh apples, 
oilseeds, frozen raspberries, sugar, sunflower oil, cigarettes, etc. On the other hand, Serbia is dominantly imported tobacco, coffee, banana and citrus fruits, frozen pork meat, natural rubber, etc. (CEVES, 2017; RAS, 2019).

Table 3. Basic indicators in foreign trade of agri-food products (period 2010-2019., in million EUR)

\begin{tabular}{|l|r|r|r|r|r|r|r|r|r|r|}
\hline \multicolumn{1}{|c|}{ Description } & 2010. & 2011. & 2012. & 2013. & 2014. & 2015. & 2016. & 2017. & 2018. & 2019. \\
\hline Import & 1,700 & 1,956 & 2,131 & 2,104 & 2,338 & 2,605 & 2,922 & 2,823 & 2,854 & 3,238 \\
\hline Export & 819 & 1,053 & 1,221 & 1,117 & 1,292 & 1,489 & 1,362 & 1,617 & 1,714 & 1,868 \\
\hline Balance & 881 & 903 & 910 & 987 & 1,047 & 1,117 & 1,560 & 1,206 & 1,140 & 1,370 \\
\hline Volume of exchange & 2,519 & 3,009 & 3,352 & 3,221 & 3,630 & 4,094 & 4,284 & 4,440 & 4,568 & 5,106 \\
\hline Export/Import (in \%) & 207.6 & 185.8 & 175.0 & 188.4 & 181.0 & 175.0 & 214.5 & 174.6 & 166.5 & 173.3 \\
\hline $\begin{array}{l}\text { Share of export in total } \\
\text { export (in \%) }\end{array}$ & 23.0 & 23.2 & 24.1 & 19.0 & 20.8 & 21.6 & 21.8 & 18.8 & 17.5 & 18.5 \\
\hline $\begin{array}{l}\text { Share of import in total } \\
\text { import (in \%) }\end{array}$ & 6.6 & 7.4 & 8.3 & 8.0 & 8.0 & 9.1 & 7.8 & 8.3 & 7.8 & 7.8 \\
\hline
\end{tabular}

Source: SORS, 2020; MAFWM, 2020.

The volume of foreign trade balance in agri-food products has positive trend in observed period (Table 3.). In 2019. it increased more than twice compared to the initial year (5,106 vs. 2,519 million EUR). Specifically, compared to 2010. exports in 2019. are for over $90 \%$ higher, while in same time distance imports jumped for around $128 \%$.

In entire period, exports are overcoming the imports (Table 3.), where the positive balance from 2010. (881 million EUR) has been increased in 2019. for more than $55 \%$ (1,370 million EUR). The share of agricultural exports in overall exports was decreased from $23 \%$ in 2010 . to $18.5 \%$ in 2019 . On the other hand, in same period the share of agricultural imports in total imports was increased from $6.6 \%$ to $7.8 \%$.

Table 4. Share of agriculture, forestry and fishery in GDP and total employment (period 2015-2019.)

\begin{tabular}{|l|r|r|r|r|r|}
\hline \multicolumn{1}{|c|}{ Description } & \multicolumn{1}{c|}{$\mathbf{2 0 1 5 .}$} & \multicolumn{1}{c|}{$\mathbf{2 0 1 6 .}$} & \multicolumn{1}{c|}{$\mathbf{2 0 1 7 .}$} & \multicolumn{1}{c|}{$\mathbf{2 0 1 8 .}$} & \multicolumn{1}{c|}{$\mathbf{2 0 1 9 .}$} \\
\hline GVA in current prices (in mil. RSD) & 289,168 & 307,541 & 286,245 & 321,481 & 333,254 \\
\hline Share in total GVA (in \%) & 8.0 & 8.2 & 7.3 & 7.7 & 7.4 \\
\hline Employment (in 000) & 497.8 & 506.1 & 481.1 & 451.0 & 452.7 \\
\hline Share in total employment (in \%) & 19.5 & 18.6 & 17.2 & 15.9 & 15.6 \\
\hline
\end{tabular}

Source: SORS, 2020; MAFWM, 2020.

In line to data in Table 4., within the period 2015-2019., the share of agricultural sector in total GDP at national level was stable and ranged between 7 to $8 \%$. Toward the employment, this sector absorbs significant number of employees. In observed period there was came to negative trend in employment, where employment rate in 
agriculture fall from $19.5 \%$ to $15.6 \%$ for five years. It's estimated that this trend is partly affected by increase in employment within the secondary and tertiary sectors of the national economy.

\section{State of Family Farms as Important Segment of Serbian Agriculture}

Serbia's economic policy has almost never give the full importance to the sector of family farms, unlike some developed EU countries (e.g. Switzerland, Austria, etc.). The prices of agri-food products have been always relatively lower than the prices of agri-inputs and other industrial products (price scissors), as through the lower level of food prices have been usually run the policy of the urban population life standard stabilisation. Besides, full utilization of agricultural potential could be possible only if farms are connected to the market in a way that they can generate higher income and some other benefits (Zakić et al., 2014).

The current mechanisms for the development of agriculture in Serbia are not optimal, so certain changes are needed primarily in the approach for itself. It should be done through the institutional support and credit policy that will create preconditions for the development of family farms (Bogavac Cvetković et al., 2010). To family farms has to be transferred support and education in terms of joining into the certain association (cooperatives, clusters, etc.). The modern market requires a stable and continuous supply, which cannot be fulfilled without cooperation of small production entities (Paraušić, Cvijanović, 2014).

In Serbia, there is no basic (social) infrastructure for the development of family farms, so the policy is mainly focused to solving the problems throughout the distribution of primarily subsidies. This has been caused unfavourable migrations to the urban centres or abroad. For the years, family farms are burdened with next issues: unfavourable age structure of the rural population and small estate per average family farm.

Agricultural production has to be observed as the economic activity that operates on the same principles as industry or services. Land policy needs to be reconfigured in order to get more efficient use of available land resources, i.e. to increase farm production sustainability. Besides, there are many farms that are overcapitalized (observing the ratio between the value of mechanization they own and the cultivated area or created output).

Previously mentioned was resulted in low level of net income per family farm. According to the MAFWM (based on the FADN data), in average Serbia has annual net income of 13.3 thousand EUR per farm, what is over $30 \%$ lower than the EU-28 average (17.4 thousand EUR). The highest value of annual 
net income per farm is reached in the Netherlands (around 63 thousand EUR), indicating in same time the productivity of Dutch farms.

Table 5. Family farms according to available utilized agricultural area (in ha)

\begin{tabular}{|l|r|r|r|r|}
\hline \multicolumn{1}{|c|}{ Description } & \multicolumn{1}{c|}{$\begin{array}{c}\text { Surfaces } \\
\text { (in ha) }\end{array}$} & \multicolumn{1}{c|}{$\begin{array}{c}\text { Structure } \\
\text { (in \%) }\end{array}$} & \multicolumn{1}{c|}{$\begin{array}{c}\text { Number of } \\
\text { farms }\end{array}$} & \multicolumn{1}{c|}{$\begin{array}{c}\text { Structure } \\
\text { (in \%) }\end{array}$} \\
\hline Without land & 0 & 0.00 & 5,290 & 0.94 \\
\hline Less than 1 ha & 58,683 & 1.69 & 106,587 & 18.88 \\
\hline $\mathbf{1 - 2}$ ha & 159,904 & 4.60 & 110,893 & 19.64 \\
\hline $\mathbf{2 - 5}$ ha & 589,218 & 16.95 & 182,253 & 32.28 \\
\hline $\mathbf{5 - 1 0}$ ha & 665,233 & 19.14 & 96,262 & 17.05 \\
\hline $\mathbf{1 0 - 2 0}$ ha & 556,201 & 16.00 & 40,876 & 7.24 \\
\hline $\mathbf{2 0 - 3 0}$ ha & 261,305 & 7.52 & 11,072 & 1.96 \\
\hline $\mathbf{3 0 - 5 0}$ ha & 228,204 & 6.57 & 6,062 & 1.07 \\
\hline $\mathbf{5 0 - 1 0 0}$ ha & 256,164 & 7.37 & 3,825 & 0.68 \\
\hline More than 100 ha & 700,982 & 20.17 & 1,422 & 0.25 \\
\hline Total & $3,475,894$ & 100.00 & 564,542 & 100.00 \\
\hline
\end{tabular}

Source: SORS, 2019.

According to data in Table 5., it is evident that the majority of agricultural farms in Serbia have on disposal small estate, while they cannot be economically sustainable, providing the decent life conditions for all family members (over the $86 \%$ of farms have less than 10 ha of land, what cannot mark them as market oriented). Besides, certain forms of association in rural areas are facing difficulties and do not give adequate results (e.g. renewal of cooperatives, establishment of clusters, etc.).

\section{Actual Business Results of the Companies'Active in the Sector of Agriculture}

According to the Serbian Business Report in 2019., business entities from the sector A - Agriculture, forestry and fisheries (based to submitted financial reports) were achieved positive net profit in value of 6,185 million RSD. Further, the value of used operating assets was 874,452 million RSD, while they were generated revenues in amount of 370,064 million RSD. The rate of return measured as the ratio between the realized net profit and operating assets in 2019. was 0.71 , what is significantly less than the average of entire economy (3.1), (SBRA, 2020). The ratio between the realized revenues and total assets indicates a low turnover ratio, both of fixed and total assets, what surely has a negative impact on other business indicators (e.g. profitability). Within the structure of total assets, fixed assets are significantly higher than current assets, participating with over 70\% (Table 6). 
Table 6. Trend in assets and capital in sector A (2018-2019., in million RSD)

\begin{tabular}{|l|r|r|}
\hline \multicolumn{1}{|c|}{ Description } & 2018. & \multicolumn{1}{r|}{$\mathbf{2 0 1 9 .}$} \\
\hline Unpaid subscribed capital & 591 & 379 \\
\hline Fixed assets & 614,408 & 614,517 \\
\hline Current assets & 251,861 & 258,151 \\
\hline Deferred tax assets & 1,638 & 1,404 \\
\hline Capital & 518,931 & 544,362 \\
\hline
\end{tabular}

Source: SBRA, 2019-2020.

Data presented in Tables 6. and 7. are showing the high share of capital from this sector in total assets in both observed years. Besides, capital is significantly higher than the sum of short-term and long-term liabilities, what indicates stronger reliance of the sector on its own financing assets than to borrowed capital (primarily loans). Commercial banks are reluctant to finance SMEs' active in this sector, what represents one of significant obstacles for further development and growth in competitiveness. Meanwhile, some commercial banks, specialized in financing agriculture, have been closed (e.g. Agrobanka), what reduced the overall potential for financing the sector. On the other hand, at the national level the microfinancing organizations have not been developed yet, even there is no bank for development.

Table 7. Structure of the source of financing of legal entities from the sector of agriculture (period 2017-2019., in million RSD)

\begin{tabular}{|l|r|r|}
\hline \multicolumn{1}{|c|}{ Description } & 2018. & \multicolumn{1}{c|}{$\mathbf{2 0 1 9 .}$} \\
\hline Capital & 518,931 & 544,362 \\
\hline Long-term reservations and liabilities & 135,861 & 122,425 \\
\hline Deferred tax liabilities & 9,417 & 7,886 \\
\hline Short-term liabilities & 252,019 & 246,380 \\
\hline Loss above capital & 47,729 & 46,601 \\
\hline Total liabilities & 868,499 & 874,452 \\
\hline
\end{tabular}

Source: SBRA, 2019-2020.

Within the structure of agricultural sector liabilities, short-term liabilities are dominating (two times higher than long-term liabilities), resulting the low level of liquidity. That is also proved by the ratio of current assets and short-term liabilities in both years (ratio is approaching to quite unfavourable relation $1: 1$, what is far behind the theoretically desired relation 2:1). In balance sheet of the sector in both years are presented really high losses above capital, indicating that in sector there are still many companies that have not been restructured yet, or adequately adjusted to market requirements. 


\section{Conclusion}

The results achieved by Serbian agriculture are far behind the average of the EU27 countries, as well as from available potential for development. Economic policy did not show a strategic approach towards the development of agriculture, leading to a number of negative consequences, especially in the rural part of the country. The unfavourable age structure of the rural population and generally small farm estates are among the largest issues that burden the national agriculture and family farms. Instead of development of entrepreneurial spirit and strengthening the cooperation, public support is much more focused to incentives, what proved to be insufficient to prevent negative tendencies in agriculture. Facing the problems related to financing, vertical integration and association in clusters or cooperatives, has to be a priority direction of public policy. That will boost labour productivity and competitiveness of both farms and small enterprises, as well as decrease the pressure on available agricultural budget. Changes in the structure of production have to be also achieved, aiming to increase the share of agri-food products with higher added value, opposite to current state where the raw agricultural products dominate within the production and trade.

\section{Literature}

1. Bogavac Cvetković, N., Ilić, B., Milićević, V. (2010). Globalizacija i konkurentnost agrarnog sektora Srbije. Ekonomske teme, 68(1):159-167.

2. Byerlee, D., Janvry, A., Sadoulet, E. (2009). Agriculture for Development: Toward a New Paradigm. Annual Review of Resource Economics, 1:15-31.

3. CEVES (2017). Integrated Report on Performance and Value Chain Analysis of Selected Sectors within Manufacturing Industry. Centre of Advanced Economic Studies (CEVES), Belgrade, Serbia.

4. Devetaković, S., Gavrilović Jovanović, B., Rikalović, G. (2009). Nacionalna ekonomija. Ekonomski fakultet, Beograd, Srbija.

5. GRS (2018). Law on the Budget of the Republic of Serbia for 2019. Government of the Republic of Serbia (GRS), Belgrade, Serbia, Official Gazette of the Republic of Serbia no. 95/18-20 and 72/19-3.

6. Jeločnik, M., Subić, J. (2020). Evaluation of economic efficiency of investments in organic production at the family farms. In: (Eds.) Platania, M., Jeločnik, M., Neta Gostin, I., Organic farming, eco-market and their capitalization through the entrepreneurial initiative: Course for trainers, “Alexandru Ioan Cuza” University Press, Iasi, Romania, IAE, Belgrade Serbia, pp. 261-300. 
7. Kuzman, B., Djurić, K., Mitrović, L., Prodanović, R. (2017). Agricultural budget and agriculture development in Republic of Serbia. Economics of Agriculture, 64(2):515-531.

8. MAFWM (2014). Strategy of Agriculture and Rural Development of the Republic of Serbia for the period 2014-2024. Ministry of Agriculture, Forestry and Watermanagement of the Republic of Serbia (MAFWM), Belgrade, Serbia, Official Gazette of the Republic of Serbia no. 85/14.

9. MAFWM (2015). Law on Incentives in Agriculture and Rural Development. Ministry of Agriculture, Forestry and Water-management of the Republic of Serbia (MAFWM), Belgrade, Serbia, Official Gazette of the Republic of Serbia no. 10/13, 142/14 and 103/15.

10. MAFWM (2016). Law on Agriculture and Rural Development. Ministry of Agriculture, Forestry and Water-management of the Republic of Serbia (MAFWM), Belgrade, Serbia, Official Gazette of the Republic of Serbia no. 41/09, 10/13 - other laws and 101/16.

11. MAFWM (2017). National Program for Agriculture for the period 2018-2020. Ministry of Agriculture, Forestry and Water-management of the Republic of Serbia (MAFWM), Belgrade, Serbia, Official Gazette of the Republic of Serbia no. $120 / 17$.

12. MAFWM (2018). National Rural Development Program for the period 20182020. Ministry of Agriculture, Forestry and Water-management of the Republic of Serbia (MAFWM), Belgrade, Serbia, Official Gazette of the Republic of Serbia no. 60/18.

13. MAFWM (2020). Agriculture in the Republic of Serbia in 2019: Green Book2019. Book 1, Ministry of Agriculture, Forestry and Water-management of the Republic of Serbia (MAFWM), Belgrade, Serbia.

14. Mihailović, B., Vuković, P. (2017). Critical factors for risk reduction in the Serbian agri-food sector. In: (Eds.) Wigier, M., Goral, J., Risk in the food economy: Theory and practice, IERIGZ, Warsaw, Poland, pp. 207-229.

15. Paraušić, V., Cvijanović, J. (2014). Konkurentnost agroprivrede Srbije: Klasteri u funkciji održive regionalne konkurentnosti. Institut za ekonomiku poljoprivrede, Beograd, Srbija.

16. Parausić, V., Domazet, I. (2018). Cluster Development and Innovative Potential in Serbian Agriculture. Economics of Agriculture, 65(3):1159-1170.

17. Pejanović, R., Milanović, M., Cvijanović, D. (2006). Transition of Agriculture in the Republic of Serbia: Achievements, effects and limitations, Economics of Agriculture, 53(4):937-946. 
18. RAS (2019). Serbia Food Industry. Development Agency of Serbia (RAS), Belgrade, Serbia.

19. Ristić, L. (2013). Strategijsko upravljanje održivim ruralnim razvojem u Republici Srbiji. Ekonomski horizonti, 15(3):229-243.

20. SBRA (2019-2020). Report about business activities of legal entities in Serbia in 2018 and 2019. Serbian Business Registers Agency (SBRA), Belgrade, Serbia.

21. Simonović, Z., Jeločnik, M., Vasić, Z. (2012). Economic position of Serbian agriculture in the transition period. Economics of Agriculture, 59(3):535-545.

22. SORS (2020). Statistical Yearbook of the Republic of Serbia - 2020. Statistical Office of the Republic of Serbia (SORS), Belgrade, Serbia, retrieved at: https:// publikacije.stat.gov.rs/G2020/Pdf/G20202053.pdf, 25 ${ }^{\text {th }}$ October 2020.

23. SORS (2019). Farm structure survey: Serbia 2018. Statistical Office of the Republic of Serbia (SORS), Belgrade, Serbia.

24. Stefanović, R., Broćić, Z. (2012). Kvalitet kao determinanta rasta izvoza poljoprivredno-prehrambenih proizvoda Republike Srbije. FQ2012, Association for Quality and Standardization - AQS, Kruševac, Srbija, pp. A267-A273.

25. Subić, J., Kljajić, N., Jeločnik, M. (2017). Obnovljivi izvori energije $i$ navodnjavanje u funkciji održivog razvoja poljoprivrede: Ekonomski aspekti. Institut za ekonomiku poljoprivrede, Beograd, Srbija.

26. Zakić, N., Vukotić, S., Cvijanović, D. (2014). Organisational Models in Agriculture with Special Reference to Small Farmers. Economics of Agriculture, 61(1):225-239. 